\title{
Harnessing the power of imagination
}

\author{
Book review by Elizabeth Morgan * \\ Macquarie University
}

\section{Review of Food Utopias: Reimagining Citizenship, Ethics and Community, edited by Paul V. Stock, Michael Carolan, and Christopher Rosin. (2015). Published by Routledge. Available as hardcover, Kindle eBook and iBook; 238 pages. Publisher's website: http://www.routledge.com/books/details/9781138788497/}

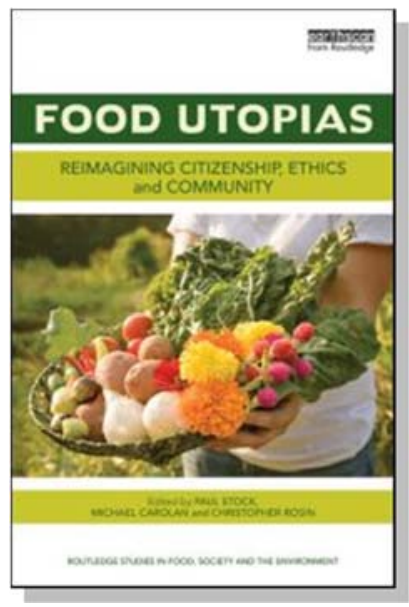

Submitted June 21, 2015 / Published online September 22, 2015

Citation: Morgan, E. (2015). Harnessing the power of imagination [Book review]. Journal of Agriculture, Food Systems, and Community Development, 5(4), 203-204. http://dx.doi.org/10.5304/jafscd.2015.054.033

Copyright (C) 2015 by New Leaf Associates, Inc.

\begin{abstract}
A $\mathrm{n}$ Irishman/Frenchman/Tunisian man is sipping his favorite tipple when he is visited by a fairy, who offers to grant him three wishes. "I'd like an ever-replenishing glass of Guinness/ Bordeaux/mint tea," says he. "No problem," she replies, and with a quick flick of her wand the man's now-empty glass is refilled to the brim, and greedily drunk. This happens several times until the fairy interrupts the man's reverie. "I'm sorry, but I can't be hanging around here all day while you get stuck into more Guinness/Bordeaux/mint tea. What is your second wish?" With nary a second's hesitation, the Irishman/Frenchman/Tunisian replies: "I'll have another one of those."
\end{abstract}

\footnotetext{
* Elizabeth Morgan is PhD candidate in the Department of Geography and Planning at Macquarie University in Sydney, Australia. Her research is on the role of local government in food security, with case studies on two local government authorities in Western Sydney. She can be contacted at elizabeth.morgan@mq.edu.au
}

This is a tired, old joke, but it is, nevertheless, a powerful parable about humankind's propensity for shortsightedness, simple foolishness, and an almost willful blindness to the value and finitude of the world's precious resources. Food is often bought, consumed, or thrown out with little consideration of its true cost-not just monetary. The pressing question is, how much longer can we be so profligate before we find ourselves in real trouble? Academics and activists have been raising the alarm about the globalized/conventional food system for quite some time, but it is probably fair to say that Food Utopias: Reimagining Citizenship, Ethics and Community is something of a trailblazer in its attempt to tackle the food conundrum by reimagining the food system through a utopian lens. The editors (two sociologists and a geographer) are to be commended for their vision, because this is an engaging, challenging, and optimistic volume of essays that are woven together by the common threads of sustainability 
and alterity. The sustainability warp leaves us with little doubt that a business-as-usual attitude toward food in the $21^{\text {st }}$ century will be disastrous and that other ways of "doing food" are crucial; the alterity weft points the way to conceptualizing and practicing food systems that are more sustainable and socially just.

Food Utopias draws on what the editors identify as the concept's three principal aspects-critique, experimentation and practice - and as such it will appeal to a wider audience than the average scholarly publication. The book is arranged into three main parts. The first, Food and Utopias, comprises two chapters: an editors' introduction (which this reviewer thinks would be better served by incorporating the thoughts in their concluding chapter, An Invitation to Food Utopias), and an historicalphilosophical-literary sketch of food and utopias, the purpose of which is to make the link between food and utopias but which again sits somewhat uncomfortably in the flow of the remaining sections and chapters. The second main section, Emergent Food Utopias, sets off with a more confident stride. It comprises six chapters that, in their various ways, explore and critique some practical alternative ways of doing food, ranging from nanotechnology to the Slow Food movement. It concludes with an accessible discussion of the theory and praxis of food utopias and the hopeful message that we could indeed "seize upon the present possibilities" to construct alternative worlds and effect social change, as David Harvey argued about cities more than 40 years ago (Harvey, 1973, p. 313).

This chapter, by one of the editors, Michael Carolan, tees up the reader nicely for the third main section, Food, Ethics and Morality, in which three separate authors use case studies to extrapolate what new food utopias do, and could, look like. The empirical work analyzes the work of the Land Institute (founded by Wes Jackson, who writes a foreword to the book) in developing sustainable agricultural systems; Biosphere 2, a closed ecological system in the Arizona desert; and the Catholic Worker Movement intentional communities based on faith and social justice principles. Finally, there is a thought-provoking and entertaining look at the politics of food (titled
Spurlock's Vomit and Visible Food Politics), which posits how utopias can be used as tools not just to critique the dominant industrialized food system (as Morgan Spurlock did in Super Size Me, his documentary on McDonald's), but to stand at a distance from it, resist and challenge it, and forge workable alternatives.

The emergence of the Slow Food movement in direct opposition to the steady march of fastfood chain McDonald's is addressed in the chapter Slow Food Presidia: The Nostalgic and the Utopian. It is potentially problematic because it neglects to address the very globalization and corporatization characteristics of McDonald's that the global Slow Food movement itself exhibits (for example, see Sheringham, 2008). However, this is a small weak point in an otherwise excellent body of work that makes a solid argument for using utopian theories and practices to get us out of the mess we are indubitably in. Overall the book is a thoughtful, critical, robust, and hopeful collection of meditations on one of life's most essential ingredients: food.

The editors' concluding chapter, Food as Mediator: Opening the Dialogue Around Food, brings the reader full circle to the book's principal aims: to harness the power of food narratives and use utopian theories as sounding boards to stimulate new dialogues about just and sustainable food systems. It is also unashamedly a clarion call to every individual who is concerned about the future of food to use the relational tools of critique/ scholarship and experimentation and, building on these two foundations, enact change by processwhat the editors describe as a recognition "that new ideas and experiments coming from the margins of society need space to incubate" (p. 10). In other words, utopias.

\section{References}

Harvey, D. (1973). Social justice and the city. London: Edward Arnold.

Sheringham, C. J. (2008). A gastronomic meditation: On $M c$ Donald's (Doctoral dissertation). University of Western Sydney, Australia. http://researchdirect.uws.edu.au/islandora/object/ uws $\% 3$ A3790/datastream/PDF/view 